\title{
Improving Students Science Process and Critical Thinking Skills Using Semi-Research Patterns Practicum
}

\author{
Iis Siti Jahro ${ }^{*}$, Ayi Darmana ${ }^{1}$, and Ani Sutiani ${ }^{1}$ \\ ${ }^{1}$ Department of Chemistry Education, Faculty of Math and Science, \\ Universitas Negeri Medan, Jl. William Iskandar PS. V, Percut Sei Tuan, Deli Serdang, 20371, \\ Indonesia \\ *Email: iissitijahro@unimed.ac.id
}

Received: 16 April 2021; Accepted: 17 June 2021; Published: 30 June 2021

\begin{abstract}
The old pattern of practicum implementation has less impact on increasing students' science process skills and critical thinking. Therefore, implementing practicum with a semi-research pattern has been carried out by involving the lecturer and laboratory assistant. The subjects of this research were 40 students in Universitas Negeri Medan. The method is classroom action research consisting of two cycles. Each cycle includes planning, action, reflection, and evaluation. Instrument's research is the observation sheet and essay test. The results of descriptive data analysis show that implementing practicum with a semi-research pattern can improve students' science process critical thinking skills, especially in planning experiments by $88.3 \%$ and critical thinking skills in evaluating by $82.3 \%$.
\end{abstract}

Keywords: critical thinking skills, semi-research pattern practicum, science process skills

DOI: https://doi.org/10.15575/jtk.v6i1.8378

\section{Introduction}

Practicum activities hold an important role in science learning, especially chemistry, which is an experimental science. Chemistry is built on a product, process, and scientific attitude (Trianto, 2010). Therefore, chemistry can not be learned only through reading, writing, or listening. Mastery of chemistry is measured through the ability to master a collection of chemical knowledge and the skills to do scientific work (Altun et al., 2009). Practicum activities are a means to do scientific work, applying Science Process Skills (SPS), and Develop Critical Thinking Skills (CTS). In addition, the practicum implementation is expected to provide evidence for the truth of the theories or concepts that have been learned by students so that the theories or concepts become more meaningful in their cognitive structure (Hamidu et al., 2014).
The Non-Metal Chemistry course is an Inorganic Chemistry group course with a weight of four credits divided into two activities, namely theoretical and practical lectures (Tim Kurikulum, 2013). The practicum implementation is expected to improve students' mastery of Non-Metal Chemistry knowledge and SPS and CTS. Furthermore, this can provide students with research, such as simple research to fulfill Mini Research Tasks which are mandatory tasks for every Unimed (Universitas Negeri Medan) students in each semester.

The observations and evaluations results of the implementation of the Non-Metal Chemistry Practicum for approximately 2 years (2017-2018) were found; (1) Most students do practicum without any preparation, either knowledge or SPS that are needed in the implementation of practicum, (2) Students do practicum according to the procedures contained in the Practicum Guide without 
Improving Students Science Process and Critical Thinking Skills Using Semi-Research Patterns Practicum

knowing the aims and objectives, (3) There is no difference in the pattern of practicum implementation in the course of Non-Metal Chemistry and General Chemistry as well as Basic Chemistry. Each of them uses the old pattern, where students read the guidebook and then carry out the experiment according to the tools and materials and the procedures written in the practicum guide. Therefore, the old pattern of implementing this practicum has no impact on increasing student mastery of the chemical material they have studied and their SPS and CTS (Jahro et al., 2017).

Practicum is the right activity to apply SPS and develop CTS. Science process skills are abilities or skills to use thought, reasoning and actions in learning science, including observing, classifying, interpreting, predicting, asking questions, formulating hypotheses, using tools and materials, planning experiments, and communicating (Noor \& Wilujeng, 2015).

Critical thinking can be interpreted as a person's attempt to check the truth of information using evidence, logic, and bias awareness. There are five critical thinking skills that can be developed through practical activities: analyzing, synthesizing, recognizing and solving problems, concluding and evaluating or assessing (Liliasari, 2009).

This research has been carried out to study applying a new pattern or model of practicum implementation named the Semi-Research Pattern Practicum. This is done to improve the quality of the practical implementation of the Non-Metal Chemistry course. Three components hold an important role in implementing the Semi-Research Pattern Practicum, namely (1) the Practicum Guide, which contains several questions in each section to develop student CTS and practicum procedures that allow students to optimize SPS and conduct simple research or mini research. (2) Supervision activities using a guided inquiry approach. (3) Authentic assessment.

Therefore, in this action research, the following problems were formulated: (1) What is the peculiarity of the implementation of the semi-research pattern practicum? (2) Can the application of the semi-research pattern practicum improve students' SPS and CTS? (3) What aspects of SPS and CTS experienced the greatest improvement in the implementation of the semi-research pattern practicum?

Following the problems that have been formulated, this action research has the aim of increasing students' SPS and CTS and getting a new pattern of implementing the Non-Metal Chemistry practicum.

\section{Research Method}

This research is action research or classroom action research consisting of two cycles where each cycle includes the stages of planning, action, reflection, and evaluation, as shown in Figure 1.

This research was conducted at the Department of Chemistry, FMIPA, Universitas Negeri Medan, in the 2018/2019 academic year with a sample of 40 semesters III students taking Non-Metal Chemistry courses from two classes.

There are two data collection instruments used, namely the Observation Sheet and Essay Test, with 20 questions used for the initial and final test. So, the questions used in the initial test and the final test are the same, but the implementation is slightly different according to the stages of action research. In the initial test, all 20 essay questions are given before implementing the research and done by students within two hours or 120 minutes. 


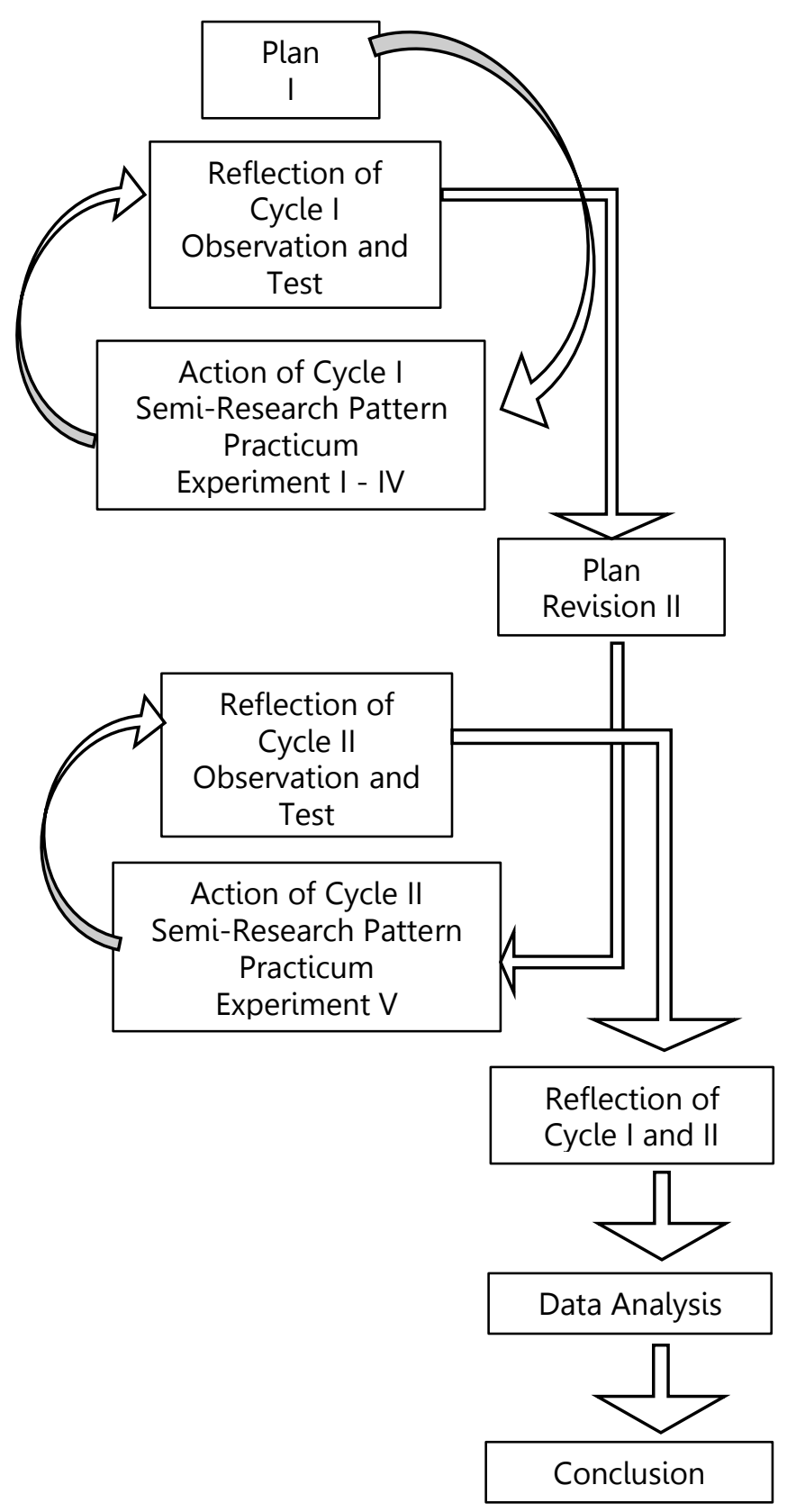

Figure 1. Stages of Action Research

As for the final test, which was carried out two times, namely at the reflection stage of cycles I and II, the 20 description questions were divided by two so that in each final test, ten questions were used, which must be completed each within one hour or 60 minutes.

The Developmental Practicum Guide was also used in this study, which was named the NonMetal Chemistry Semi Research Practicum Guide, which contained eight experimental titles. Still, only four experiments were tested in the first cycle because, in the second cycle, experimental titles were carried out using a practicum guide compiled by each group of students in the form of simple research. In addition, it is also adjusted to the available time allocation for the preparation, implementation, and reporting of research results.

There were 40 students from two classes consisting of eight boys and 32 girls who were the research subjects. The students were divided into eight groups that were arranged heterogeneously based on their ability level and gender. There were students with high, medium, and low abilities in each group based on their GPA scores and male and female students. Each group of students carried out four experiments in turn. Groups 1-2, 3-4, 5-6, and $7-8$ in the first week, conducted experiments I, II, III and IV, respectively. Then in the second week, the sequence becomes II, III, IV and I and so on until each group has the opportunity to do all the experiments I-IV. The theme or title of the experiments carried out in the first cycle of action in a row for experiments I, II, III and IV regarding the characteristics of elements and compounds: Boron, Nitrogen, Sulfur, and Halogens.

Before students do each practicum, an oral test is carried out by a practicum supervisor per group so that there are eight practicum supervisors for eight groups of students. This oral test is given to determine student mastery of the basic theory, working methods, and data processing of the practicum results that will be carried out. This oral test consists of five limited description questions for each practicum and is called the initial test before the practicum or student preparation test.

During the practicum activities, supervision and guidance are carried out using a guided inquiry approach and student CTS through questions asked orally. In addition, SPS assessment or measurement is also carried out using an Observation Sheet instrument that an expert validator has validated. The Observation Sheet contains ten statements, each of which is given a rating scale of 1-5 with 
the following criteria: very less, less, enough, good, and very good. Finally, after all, students have completed the practicum, the reflection stage is carried out to measure SPS and CTS using an essay test.

Based on the results of the evaluation of the implementation of each activity stage in cycle $I$ and the data from the SPS and CTS measurement results, then the activities in cycle II are arranged. Thus, the activities in Cycle II were almost the same as in Cycle I. However, in Cycle II, the experimental guides used, ranging from experimental objectives, tools, and materials to the procedures, were prepared by each group of students. Thus, the experimental procedure in cycle II is a simple research procedure or semi-research that reflects the SPS and CTS that students have achieved.

\section{Result and Discussion}

In this research, a series of activities were carried out as follows: giving initial test before carrying out action research, preparing student tests before doing each practicum in both cycles I and II, implementing practicum using a semi-research practicum guide in cycle I and practicum guide prepared by each group of students in cycle II, mentoring by one supervisor for each group of students with an inquiry approach in each practicum implementation, allowing preparing an experimental guide and two times final test each after students complete all experimental titles in both of cycle.

\subsection{Implementation Results of Student Preparation Tests Before Conducting Practicum in Cycle I}

The student preparation test before doing the practicum is a test given by a practicum supervisor to each student per group. This test is conducted orally with five questions for approximately 30 minutes. In this preparation test, topics regarding the theoretical basis, working methods, and data processing of the results of the practicum will be tested. The questions asked are adjusted to the demands of the SPS and CTS.
The average student preparation test results per group before conducting experiments I, II, III and IV were 44.6; 54.8; 63.4 and 72.4, respectively, which indicates the average score of the initial test is increasing. It is reasonable to suspect that giving students preparation tests before practicum can encourage students to improve their knowledge and skills preparation before practicum. The SPS and CTS assessment results support this assumption at the time of the practicum implementation, increasing from the experiment I to IV, as shown in Table 1.

\subsection{Implementation Results of Semi- Research Practicum Guide and Guided Inquiry Approach in Cycle I}

The components in the Semi-Research Practicum Guide, especially the tools and materials used and the experimental procedures, require students to optimize SPS and CTS. The tools and materials listed in the Semi-Research Practicum Guide are not limited to the tools and materials available in the laboratory. Still, they are provided with alternative tools and materials that can be found in everyday life. In addition, the tool is not given specific information about the type and size. This encourages students to determine the tools to be used according to the functions and experiments they will do. As an example of the sulfide acid reactivity test, the following experimental procedure is listed: In a large pyrex test tube, add $20 \mathrm{~mL}$ of paraffin, one spoon of sulfur, and a piece of asbestos. Heat the test tube and check the gas formed with filter paper dripped with $\mathrm{Pb}\left(\mathrm{CH}_{3} \mathrm{COO}\right)_{2}$ solution. Meanwhile, large pyrex test tubes are not available on the lab table. There are $20 \mathrm{ml}$ pyrex tubes and $50 \mathrm{ml}$ ordinary (not pyrex) test tubes, so students must determine which option to use. If students choose an ordinary $50 \mathrm{ml}$ test tube, there is a risk that the tube may burst when heated at a relatively high temperature for a long time. If the student chooses a $20 \mathrm{ml}$ pyrex test tube, the student must reduce all substances used to half of what they should be so that when heated, the substance does not spill out of the tube or spill. The activity or process of students determining the choice of test tubes to be used and finding the risks or 
Improving Students Science Process and Critical Thinking Skills Using Semi-Research Patterns Practicum

consequences that must be borne from using these test tubes, and deciding or concluding the test tubes to be used is an indicator that students are optimizing SPS planning experiments and CTS evaluating or assessing.

The experimental procedures listed in the Semi-Research Practicum Guide open opportunities or encourage students to conduct simple trials or research because the procedures provided are not rigid but flexible. For example, in the nitric acid reactivity test, the following experimental procedure is listed: In a test tube containing $10 \mathrm{~mL}$ of $7 \mathrm{M} \mathrm{HNO}_{3}$, add copper metal chips. Check or prove that the gas formed from the reaction is acidic. In this procedure, students are given the freedom to determine the number and weight of copper metal pieces and the type of material or tool to check that the gas produced is acidic. This procedure encourages students to optimize SPS by asking questions, applying concepts, formulating hypotheses, and planning experiments. In addition, it also develops CTS to recognize and solve problems as well as evaluate or assess.

Guidance is carried out using an inquiry approach during the practicum implementation to help students optimize SPS and CTS. This is in line with the study results, which revealed that the inquiry-based practicum method plays an important role in science learning and improves the application of SPS when conducting experiments (Bruck \& Town, 2009). The inquiry approach consists of free inquiry and guided inquiry. In guided inquiry, guidelines are used in structured questions that lead to an action or conclusion (Mulyasa, 2006; Suyanti, 2010; Istarani, 2012).

Therefore, the Semi-Research Practicum Guide is equipped with several questions asked when students are conducting experiments. For example, when a student conducts a nitric acid reactivity test with the procedure described above, several questions are asked as follows: (1) Does the copper chip that will be reacted need to be weighed first? Explain why? (2) How to prove that the gas produced is acidic? (3) Is the volume of gas produced affected by the number or weight of the copper pieces that are reacted? How to prove it? Based on the answers submitted by students, students are allowed to prove it directly on the spot.

Based on the inquiry-based mentoring provided, it turned out that most students were able to optimize SPS and develop CTS so that they experimented with the following procedure: the copper metal used varied from 1 piece, 2 pieces and so on by being weighed first to prove the effect of weight and amount of copper metal chips used on the gas content produced. In addition, students also tried various ways to prove that the gas produced was acidic, such as using blue litmus paper, red litmus paper, universal indicator, and then filter paper with $\mathrm{NaOH}$ and phenolphthalein as an indicator. Experimental procedures carried out by students using variations in copper weight and various ways of proving acidic gases reflect simple research procedures or mini research.

The assessment results using the observation sheet and test instruments showed that students' SPS and CTS were increasing in implementing experiments I to IV in line with the increase in the initial tests they achieved, as shown in Table 1.

Table 1. Average Student Preparation Test Scores, SPS and CTS in the Implementation of Experiments I-IV

\begin{tabular}{ccccc}
\hline \multirow{2}{*}{$\begin{array}{c}\text { Assessment } \\
\text { Results }\end{array}$} & \multicolumn{4}{c}{$\begin{array}{c}\text { On the Implementation of } \\
\text { Experiment }\end{array}$} \\
\cline { 2 - 5 } & I & II & III & IV \\
\hline $\begin{array}{c}\text { Student } \\
\text { Preparation }\end{array}$ & 44.6 & 54.8 & 63.4 & 72.4 \\
$\quad$ Test & & & & \\
SPS & 46.5 & 53.8 & 64.5 & 80.3 \\
CTS & 40.5 & 47.5 & 58.3 & 72.3 \\
\hline
\end{tabular}

Based on the data analysis results on preparation test scores, SPS and CTS, each student shows that students who get high initial test scores or prepare well when experimenting show good SPS and CTS and vice versa.

There are five SPS measured in this research, namely predicting, asking questions, formulating hypotheses, planning experiments, and applying concepts. The 
Improving Students Science Process and Critical Thinking Skills Using Semi-Research Patterns Practicum

implementation of the practicum from the first experiment to the next experiment shows that every aspect of SPS has increased higher, as shown in Table 2.

Table 2. SPS Improvement on the Implementation of Experiment I-IV

\begin{tabular}{lccc}
\hline \multirow{2}{*}{ SPS Aspects } & \multicolumn{3}{c}{$\begin{array}{c}\text { SPS Improvement (\%) of } \\
\text { Experiment }\end{array}$} \\
\cline { 2 - 4 } & I to II & II to III & III to IV \\
\hline $\begin{array}{l}\text { Predicting } \\
\text { Asking }\end{array}$ & 9.3 & 13.5 & 20.3 \\
$\begin{array}{l}\text { questions } \\
\begin{array}{l}\text { Formulating } \\
\text { hypotheses }\end{array}\end{array}$ & 7.5 & 14.3 & 22.3 \\
$\begin{array}{l}\text { Planning } \\
\text { experiments }\end{array}$ & 7.5 & 12.3 & 21.5 \\
$\begin{array}{l}\text { Applying } \\
\text { concepts }\end{array}$ & 7.3 & 15.5 & 23.5 \\
\hline
\end{tabular}

Based on the data in Table 2, it can be determined that the improvement percentage in each aspect of SPS from the experiment I to IV for predicting, asking questions, formulating hypotheses, planning experiments, and applying concepts are 43.1; $45.1 ; 41.3 ; 48.3$ and $41.3 \%$ respectively. It appears that of the five aspects of SPS, planning an experiment with the highest increase is $48 \%$. This shows the impact of the implementation of practicum with a semiresearch pattern, which involves initial test activities, semi-research practicum guides, and guidance with a guided inquiry approach.

Like SPS, five CTS measured, namely analyzing, synthesizing, recognizing and solving problems, concluding and evaluating or assessing. However, of the five aspects of CTS assessed, recognizing and solving problems and the evaluation showed a greater improvement than the other aspects, as shown in Table 3.
Table 3. CTS Improvement on the Implementation of Experiment I-IV CTS Improvement (\%) of CTS Aspects $\quad$ Experiment

\begin{tabular}{lccc} 
& I to II & II to III & III to IV \\
\hline Analyzing & 7.3 & 11.5 & 17.3 \\
$\begin{array}{l}\text { Synthesizing } \\
\begin{array}{l}\text { Recognizing } \\
\text { and solving } \\
\text { problems }\end{array}\end{array}$ & 7.5 & 11.5 & 17.3 \\
$\begin{array}{l}\text { Concluding } \\
\begin{array}{l}\text { Evaluating or } \\
\text { assessing }\end{array}\end{array}$ & 7.3 & 12.3 & 22.3 \\
\hline
\end{tabular}

Based on the data in Table 3, it can be determined that the increase in each aspect of CTS from experiment I to IV for analyzing, synthesizing, recognizing and solving problems, concluding and evaluating or assessing is $36.1 ; 36.3 ; 42.1 ; 37.1$ and $41.3 \%$, respectively.

\subsection{Implementation Results of Giving Practicum Guide Preparation Tasks in Cycle I}

After the students completed all the experiments at the end of the first cycle, they were compiling a practicum guide. The practicum guide contains one semi-research experiment title based on the experiences students got from carrying out the four experiments. In addition, they are also supported by their understanding of physical properties, chemical properties, typical reactions, and how to obtain non-metallic elements from their compounds studied in Non-Metal Chemistry lectures.

The practical guide that each group of students has prepared is presented in front of a team of research lecturers, reviewers, student assistants, and their classmates. During the presentation, a question-andanswer session was conducted to determine the students' mastery of the practicum guide they had prepared. Based on the validation results obtained, four experimental titles that are feasible to be tested without revisions are feasible to be tested with minor revisions, and two are less feasible. 
Students' process when compiling a practicum guide requires students to optimize SPS and develop CTS. The most important aspect of SPS is planning an experiment which includes determining the problem or object to be investigated, determining the variables to be measured, the tools and materials to be used, and the experimental procedures to be carried out. The most developed aspects of CTS are recognizing and solving problems as well as evaluating or assessing.

\subsection{Implementation Results of Semi- Research Pattern Practicum in Cycle II}

In Cycle II, the activities were almost the same as in Cycle I. However, in Cycle II, the experimental guidelines used were prepared by students. Therefore, the experimental procedure in cycle II is a simple research procedure or semi-research that reflects the SPS and CTS that students have achieved.

There are four titles of experiments carried out in the action of cycle II, namely (1) production of hydrogen gas from the hydrolysis reaction of water with various variables of water sources and catalysts used, (2) production of hydrogen gas from the hydrolysis reaction of water with variable types of anode and cathode and source of electric current used, (3) production of hydrogen gas from the reaction of aluminium foil and caustic soda with variable weight and size of aluminium foil used, (4) production of hydrogen gas from the reaction of transition metals and Arrhenius acid with variable types of transition metals and Arrhenius acid used. Each of these experiments was carried out by two groups of students who compose them, namely experiments (1), (2), (3) and (4) were carried out by groups 1 and 3; 2 and 5; 4 and 6; 7 and 8 , respectively.

The average value of the preparation tests, SPS, and CTS, achieved by students in cycle II, was 85.8, 92.3, and 86.5, respectively. The average values in cycle II higher than in cycle I. This is the impact of implementing the semiresearch pattern practicum, especially on the implementation of experimental procedures and assistance based on an inquiry approach that uses structured questions in its guidance.
In addition, the increase in the value of the preparation tests, SPS and CTS, in cycle II was due to students preparing the experimental guide by themselves so that students mastered the guide's contents. Therefore, at the time of its implementation, it optimised SPS and CTS very well.

In Cycle II, each aspect of the SPS in predicting, asking questions, formulating hypotheses, planning experiments, and applying concepts increased by $36.3 ; 38.5 ; 37.3 ; 40.5 ; 38.2 \%$, respectively. Again, it seems that planning the experiment experienced the highest increase. This is seen through measurements using observation sheets that show students can master the problem or object they are investigating, the variables that must be measured and observed, and the experimental procedures they carry out.

The same thing is shown in the CTS; each aspect of the CTS increases $28.3 ; 28.5 ; 32.5$; 29.3 , and $30.8 \%$, respectively, for analyzing, synthesizing, recognizing and solving problems concluding and evaluating or assessing. Aspects of recognizing and solving problems and evaluating have increased higher than other aspects. This shows that students can recognize and solve problems well and can evaluate the results appropriately.

Like research in general, before and after implementing the treatment or action, the research subject is given a pre-test, and a final test regarding all treatments carried out. The initial test in the form of description questions amounted to 20 given before the first cycle. In contrast, the final test was carried out two times, namely at the reflection stage of cycles I and II. The questions were divided by two so that each amounted to ten questions. The test is used as an instrument to measure the mastery of knowledge, SPS, and CTS (Rezba et al., 2007). Assessment of science process skills is rather difficult to do through written tests compared to observation techniques. However, using a combination of both written and observational test assessment techniques can increase the accuracy of the assessment of science process skills (Akinbobola \& Afolabi, 
Improving Students Science Process and Critical Thinking Skills Using Semi-Research Patterns Practicum

2010). Therefore, in this study, the SPS and CTS assessments were carried out using observation techniques carried out when students conducted experiments and written tests in the form of description tests carried out before and after the implementation of actions in cycles I and II.

The average value of each aspect of SPS and CTS in the initial and final tests and their improvement is summarized in Table 4.

Table 4. Average Value of Each Aspect of SPS and CTS in the Initial and Final Test and their Improvement

\begin{tabular}{lccccc}
\hline \multirow{2}{*}{ Assessed Aspects } & \multicolumn{5}{c}{ Average Value of } \\
\cline { 2 - 6 } & Initial Test & $\begin{array}{c}\text { Final Test } \\
\text { of Cycle I }\end{array}$ & $\begin{array}{c}\text { Improvement } \\
\text { (\%) }\end{array}$ & $\begin{array}{c}\text { Final Test } \\
\text { of Cycle II }\end{array}$ & $\begin{array}{c}\text { Improvement } \\
\text { (\%) }\end{array}$ \\
\hline Science Process Skills: & & & & & \\
Predicting & 37.5 & 61.3 & 63.5 & 70.0 & 86.7 \\
Asking questions & 40.8 & 68.5 & 67.9 & 76.2 & 86.8 \\
Formulating hypotheses & 38.5 & 61.7 & 60.3 & 71.0 & 84.5 \\
Planning experiments & 39.3 & 67.1 & 70.7 & 74.0 & 88.3 \\
Applying concepts & 37.8 & 62.9 & 66.4 & 70.4 & 86.3 \\
Critical Thinking Skills: & & & & & \\
Analyzing & 38.5 & 63.5 & 64.9 & 66.4 & 72.5 \\
Synthesizing & 37.8 & 62.5 & 65.3 & 64.8 & 71.5 \\
Solving problems & 37.5 & 63.8 & 70.1 & 66.9 & 74.3 \\
Concluding & 37.3 & 62.3 & 67.0 & 64.5 & 72.8 \\
Evaluating or assessing & 36.3 & 63.8 & 75.8 & 67.0 & 82.3 \\
\hline
\end{tabular}

Table 4 shows that the average improvement value of each aspect of SPS in the initial and final test (both cycles) were predicting (86.7\%), asking questions (86.8\%), formulating hypotheses (84.5\%), applying concepts $(86.3 \%)$ and the highest increase that experienced in both cycles was planning an experiment with a percentage increase of $88.3 \%$. This is following the actions given to students during the practicum in the form of using a semi-research practicum guide and mentoring with an inquiry approach. This is also reinforced by the act of giving the task of compiling a practicum guide with work procedures that reflect simple research or semi-research. These two actions encourage students to optimize SPS in planning experiments, including determining experimental subjects or themes, setting experimental variables, selecting tools and materials used, and compiling experimental procedures.

While in CTS aspect, the average improvement value of each aspect in the initial and final test (both cycles) were analyzing (72.5\%), synthesizing (71.5\%), solving problems
(74.3\%), concluding (72.8\%) and the data that experienced a higher increase were evaluating or assessing with a percentage increase of $82.3 \%$. This is in line with the aspects of the SPS, Therefore, during the practicum, students receive assistance with an inquiry approach using several structured questions that require students to develop the ability to evaluate or assess every answer submitted to each question posed. Likewise, when compiling an experimental guide, students must evaluate or assess the accuracy of selecting tools and materials used following the experimental procedures. Then the suitability or accuracy of the experimental procedure with the variables to be measured or observed.

\section{Conclusion}

Implementing the semi-research pattern of the Non-Metal Chemistry practicum can improve students' scientific process skills and critical thinking skills. Planning experiments and evaluating are aspects of SPS and CTS that have been successfully improved higher than other aspects. The implementation of the semi-research pattern practicum has 
Improving Students Science Process and Critical Thinking Skills Using Semi-Research Patterns Practicum

specificity in the practicum guide and the approach used. In the semi-research practicum guide, the tools and materials and the experimental procedures are open or flexible, which allows students to carry out simple research. This is supported by assistance with an inquiry approach that uses several structured questions to direct students to find problems and variables to be studied.

Based on the results, the semi-research practicum pattern can also be used to implement other practical courses such as Analytical Chemistry, Physical Chemistry, Organic Chemistry, and Biochemistry, even very possible to do in the implementation of practicum in high school.

Implementing this semi-research pattern practicum still has several limitations, including the number of students in each group of five people, so students participate less in implementing practicum and tests. In addition, the implementation of the test before the practicum for 30 minutes per group orally is quite inconvenient in conducting the assessment, so that the assessment may be less accurate. Therefore, for further research, more forms of tests can be sought before implementing the practicum and the number of students who are more suitable for each group.

\section{References}

Akinbobola, A. O., \& Afolabi, B. (2010). Analysis of science process skills in west African senior secondary school certificate physics practical examination in Nigeria. American-Eurasian Journal of Scientific Research, 5(4), 234-240. Retrieved from http://www.idosi.org/aejsr/5(4)10/3.pdf

Altun, E., Demirdag, B., Burak, F., Alev, A., \& Iker, C. (2009). Developing an interactive virtual chemistry laboratory enriched with constructivist learning activities for secondary school. Procedia Social and Behavior Science, 1(1), 1895-1898. https://doi.org/10.1016/j.sbspro.2009.0 1.333
Bruck, L. B., \& Towns, M. H. (2009). Preparing students to benefit from inquiry-based activities in the chemistry laboratory: guidelines and suggestions. Journal of Chemical Education, 86(7), 820. https://doi.org/10.1021/ed086p820

Hamidu, M. Y., Ibrahim, A. I., \& Muhammed A. (2014). The use of laboratory method in teaching secondary school students: a key improving the quality of education. International Journal of Scientific \& Engineering Research, 5(9), 81-86. Retrieved from https://citeseerx.ist.psu.edu/viewdoc/cit ations?doi=10.1.1.685.806

Jahro, I. S., Darmana, A., \& Sutiani, A. (2017). Analisis dampak pelaksanaan praktikum terhadap penguasaan pengetahuan, keterampilan proses sains dan kemampuan berpikir kritis mahasiswa. Medan: Jurusan Kimia, FMIPA Unimed.

Istarani. (2012). 58 Model pembelajaran inovatif. Medan: Media Persada.

Liliasari (2009, September). Berpikir kritis dalam pembelajaran sains kimia. Paper presented at Workshop CTS, Medan: Universitas Negeri Medan.

Mulyasa, E. (2006). Menjadi guru professional menciptakan pembelajaran kreatif dan menyenangkan. Bandung: PT. Remaja Rosdakarya.

Noor, F. M., \& Wilujeng, I. (2015). Pengembangan LKS berbasis pendekatan CTL untuk meningkatkan keterampilan proses sains dan motivasi belajar. Jurnal Inovasi Pendidikan IPA, 1(1), https://doi.org/10.21831/jipi.v1i1.4534

Rezba, R. J., Sprague, C., McDonnough, J. T., \& Matkin, J. J. (2007). Learning and assessing science process skill. lowa: Hunt Publishing Company.

Suyanti, R.D. (2010). Strategi pembelajaran kimia. Yogyakarta: Graha Ilmu. 
Tim Kurikulum. (2013). Buku pedoman akademik. Medan: FMIPA Unimed.

Trianto (2010). Model pembelajaran terpadu. Jakarta: Bumi Aksara. 